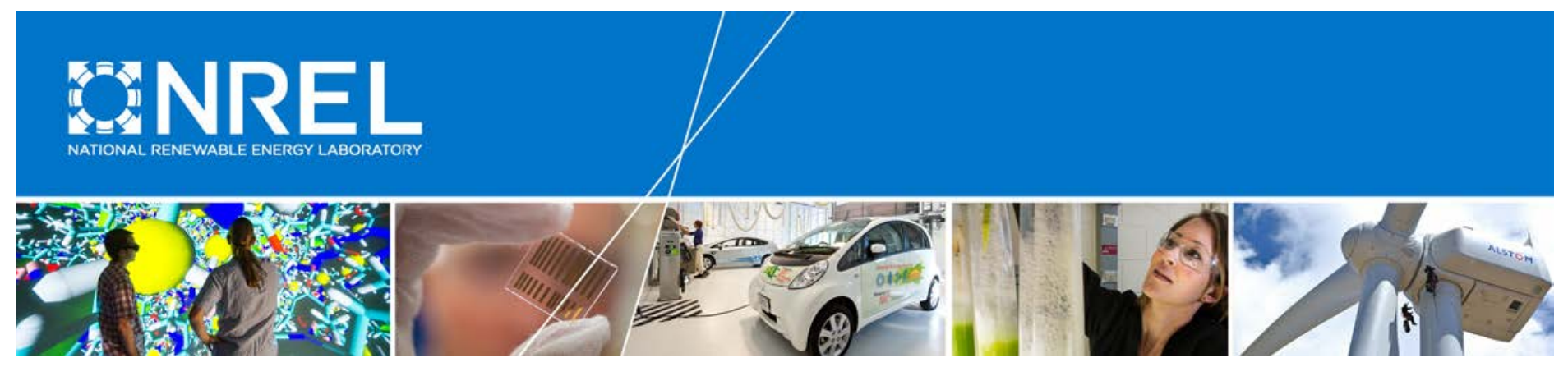

\title{
Effects of Platform Design on the Customer Experience in an Online Solar PV Marketplace
}

Benjamin D. Leibowicz and Kunal Punjabi University of Texas

Eric O'Shaughnessy and Robert Margolis National Renewable Energy Laboratory

NREL is a national laboratory of the U.S. Department of Energy Office of Energy Efficiency \& Renewable Energy Operated by the Alliance for Sustainable Energy, LLC

This report is available at no cost from the National Renewable Energy Laboratory (NREL) at www.nrel.gov/publications.

Technical Report

NREL/TP-6A20-71178

May 2018 


\section{Effects of Platform Design on the Customer Experience in an Online Solar PV Marketplace}

Benjamin D. Leibowicz and Kunal Punjabi The University of Texas at Austin

Eric O'Shaughnessy and Robert Margolis National Renewable Energy Laboratory

\section{Suggested Citation}

Leibowicz, Benjamin D., Kunal Punjabi, Eric O'Shaughnessy, and Robert Margolis. 2018. Effects of Platform Design on the Customer Experience in an Online Solar PV Marketplace. Golden, CO: National Renewable Energy Laboratory. NREL/TP-6A20-71178.

https://www.nrel.gov/docs/fy18osti/71178.pdf.
National Renewable Energy Laboratory 15013 Denver West Parkway Golden, CO 80401

303-275-3000 • www.nrel.gov
NREL is a national laboratory of the U.S. Department of Energy

Office of Energy Efficiency \& Renewable Energy

Operated by the Alliance for Sustainable Energy, LLC

This report is available at no cost from the National Renewable Energy Laboratory (NREL) at www.nrel.gov/publications.

\section{Technical Report}

NREL/TP-6A20-71178

May 2018

Contract No. DE-AC36-08GO28308 


\section{NOTICE}

This report was prepared as an account of work sponsored by an agency of the United States government. Neither the United States government nor any agency thereof, nor any of their employees, makes any warranty, express or implied, or assumes any legal liability or responsibility for the accuracy, completeness, or usefulness of any information, apparatus, product, or process disclosed, or represents that its use would not infringe privately owned rights. Reference herein to any specific commercial product, process, or service by trade name, trademark, manufacturer, or otherwise does not necessarily constitute or imply its endorsement, recommendation, or favoring by the United States government or any agency thereof. The views and opinions of authors expressed herein do not necessarily state or reflect those of the United States government or any agency thereof.

This report is available at no cost from the National Renewable Energy Laboratory (NREL) at www.nrel.gov/publications.

Available electronically at SciTech Connect http:/www.osti.gov/scitech

Available for a processing fee to U.S. Department of Energy and its contractors, in paper, from:

U.S. Department of Energy

Office of Scientific and Technical Information

P.O. Box 62

Oak Ridge, TN 37831-0062

OSTI http://www.osti.gov

Phone: 865.576.8401

Fax: 865.576.5728

Email: reports@osti.gov

Available for sale to the public, in paper, from:

U.S. Department of Commerce

National Technical Information Service

5301 Shawnee Road

Alexandria, VA 22312

NTIS http://www.ntis.gov

Phone: 800.553 .6847 or 703.605 .6000

Fax: 703.605.6900

Email: orders@ntis.gov 


\section{Acknowledgements}

This work was supported by the Solar Energy Technologies Office at the U.S. Department of Energy. The authors would like to thank Yueming Lucy Qiu (University of Maryland) and Benjamin Sigrin (NREL) for their thoughtful review of this work. The authors would also like to thank Vikram Aggarwal, Sara Matasci, and Luke Tarbi of EnergySage for their collaboration on this project, as well as Mike Meshek (NREL) and Jarett Zuboy (consultant) for editorial support. 


\section{Executive Summary}

Prospective residential solar photovoltaic (PV) customers are increasingly obtaining price quotes from installers using online quote aggregator platforms. Prospective customers provide information about their homes, electricity use, and desired PV system characteristics. They then receive quotes from local installers in a standardized format and compare the quotes based on price and system attributes. Quote aggregator platforms could streamline the PV adoption process, enhance price transparency, encourage more competitive pricing, and stimulate greater PV adoption.

In this study, we analyze a unique data set of quotes offered in the online PV marketplace EnergySage to understand how platform design changes affected quantifiable aspects of the customer experience. Specifically, we evaluate four changes: 1) adding a customer map showing potential new EnergySage registrants the locations of nearby customers, 2) applying a quote cap that precludes more than seven installers from bidding on any one customer, 3) providing a price guidance feature informing installers about competitive prices in the customer's market before they submit quotes, and 4) allowing no pre-quote messaging to prohibit installers from contacting customers prior to offering quotes. We calculate descriptive statistics to investigate whether each design change accomplished its specific objectives. Then, we econometrically evaluate the impacts of the design changes on PV quote prices and purchase prices using a regression discontinuity approach.

Descriptive statistics generally show the design changes improved the customer experience elements EnergySage intended them to address. For example, the customer map increased the conversion of website visitors into customers, the quote cap shortened waiting times for customers to receive quotes, and the price guidance feature reduced quote price dispersion. This latter effect is particularly encouraging, because price dispersion may erode customer confidence in PV adoption.

Our regression results indicate three of the four design changes lowered quote prices and purchase prices in the EnergySage platform (Figure ES-1). The effects of the fourth design were not statistically robust. The price guidance change had the strongest impact, reducing quote prices by $\$ 0.10 / \mathrm{W}$ and purchase prices by $\$ 0.15 / \mathrm{W}$, on average and holding all other factors constant. These findings are consistent with an anchoring phenomenon in installer pricing behavior, in which prices are generally pulled downward toward an anchor point reflecting competitive prices in the customer's area. 


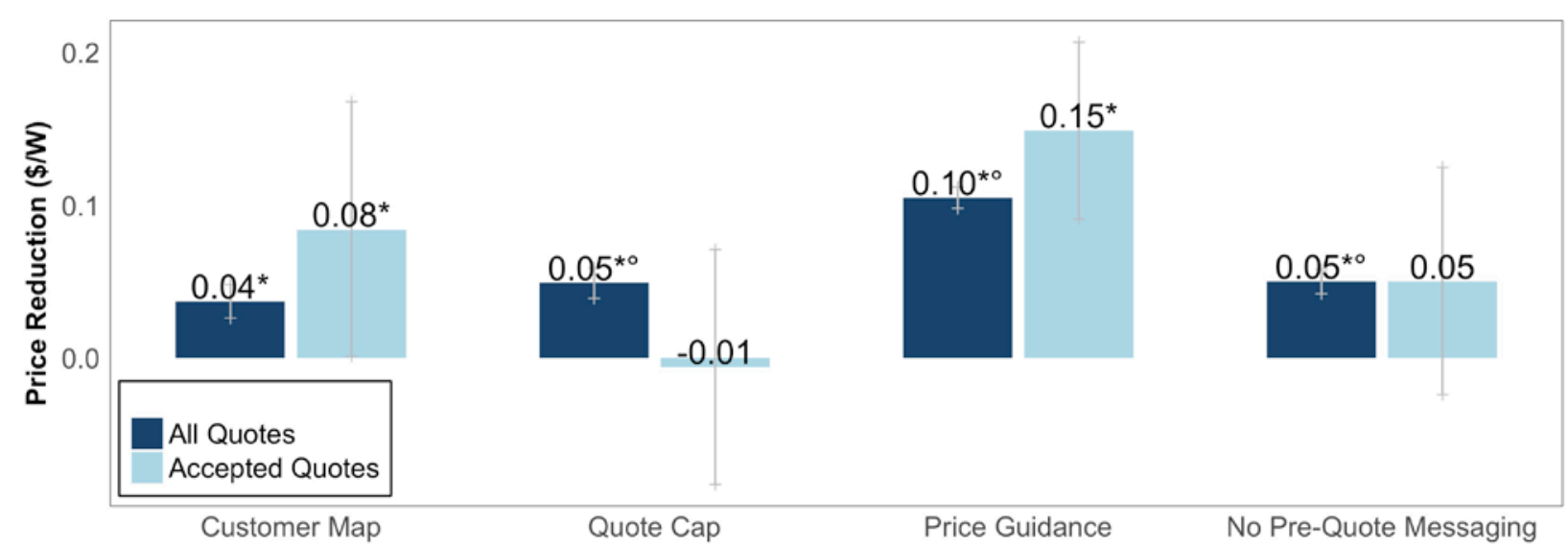

Figure ES-1. Effects on prices of the four platform design changes

Figure note: * Effect is statistically significant, ${ }^{\circ}$ effect is robust (all quotes only), effects shown with $95 \%$ confidence intervals

The regression results also provide evidence against the hypothesis that quote aggregator platforms cause PV customers to focus excessively on price at the expense of equipment quality. We find customers are willing to pay $\$ 0.64 / \mathrm{W}$ more in purchase price for systems with premiumquality PV panels than for systems with economy panels. In fact, the average premium quality markup that installers are charging in their quote prices $(\$ 0.51 / \mathrm{W})$ underestimates the additional willingness of customers to pay for high-quality panels.

Our findings have several policy implications, especially as residential PV adoption increasingly shifts toward online marketplaces. Based on the customer map results, policymakers might leverage virtual peer effects by crafting digital communication materials that educate prospective PV buyers about adoption data and trends in their communities. Our finding that the quote cap lowered prices suggests greater competition does not necessarily yield more affordable PV, so policymakers might assess some optimal degree of competition that balances the price-reducing effects of rivalry against the possibilities of opportunistic bidding and customer confusion when competition is intense. The strength of the price guidance effect implies that keeping installers up to date on competitive prices generally lowers the prices they offer and reduces price dispersion, which may improve customer confidence. The no pre-quote messaging results show that limiting contact between installers and customers can enhance transparency and shield novice customers in this fledgling industry from value-based pricing and other sales tactics. 


\section{Table of Contents}

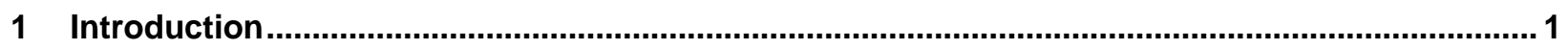

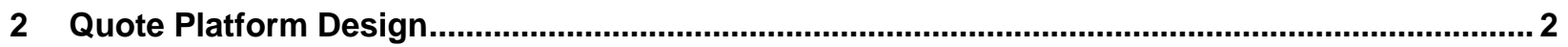

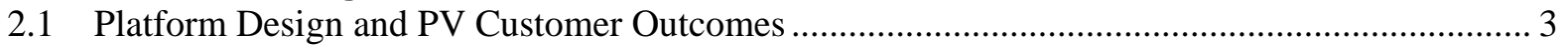

2.2 Design Changes on the EnergySage Quote Platform ............................................................... 3

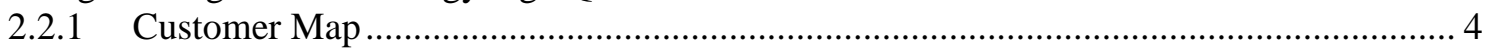

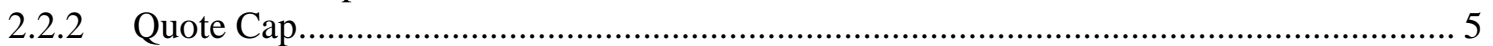

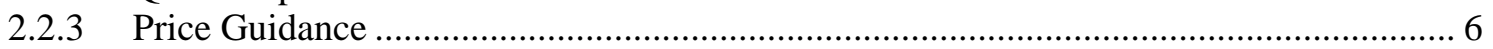

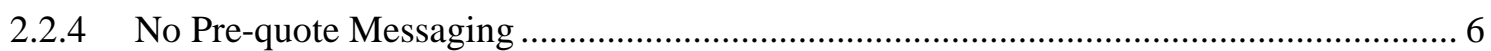

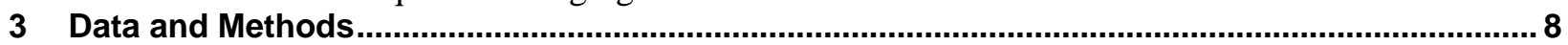

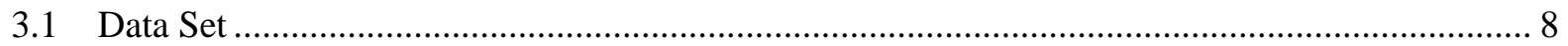

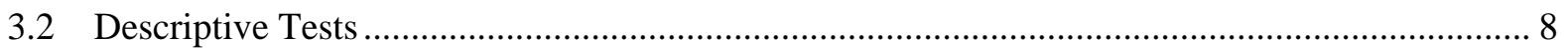

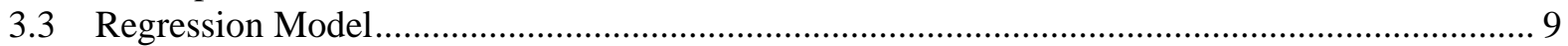

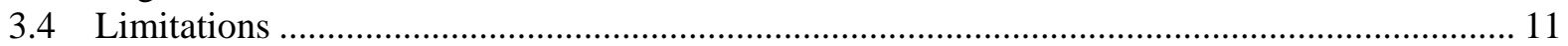

4 Results

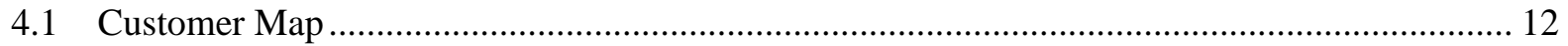

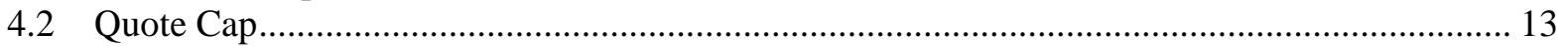

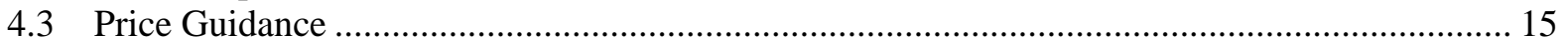

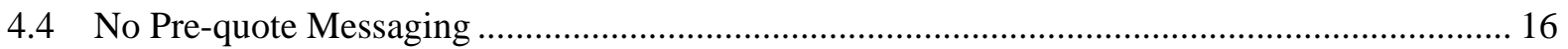

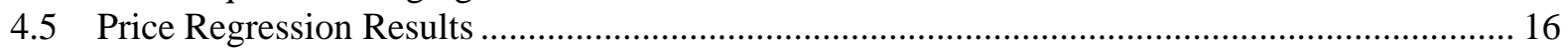

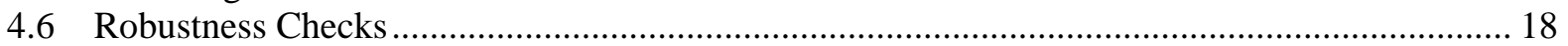

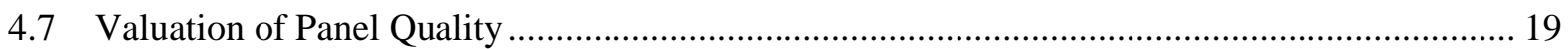

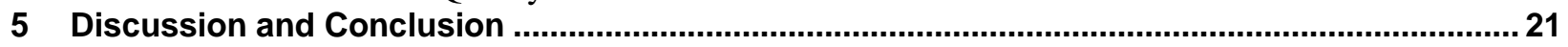

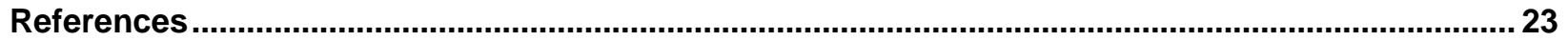




\section{List of Figures}

Figure ES-1. Effects on prices of the four platform design changes .................................................... v

Figure 1. Schematic of online PV quote platforms ...................................................................... 1

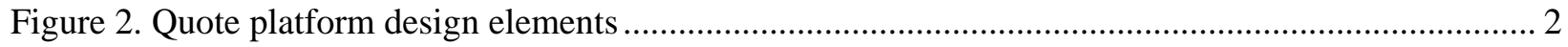

Figure 3. Screenshot of an EnergySage customer map ........................................................................ 5

Figure 4. Registration ratio before and after the customer map change ................................................. 13

Figure 5. Percentage of quotes offering premium panels before and after the quote cap change............... 14

Figure 6. Customer wait time (days between application and quote delivery) before and after the quote cap change...................................................................................................................... 14

Figure 7. Percentage of installers expressing interest in a customer and ultimately submitting a quote, before and after the quote cap change .................................................................................... 15

Figure 8. Price variability (coefficient of variation) before and after the price guidance change............... 16

Figure 9. Effects of platform design changes on quote prices .............................................................. 19

\section{List of Tables}

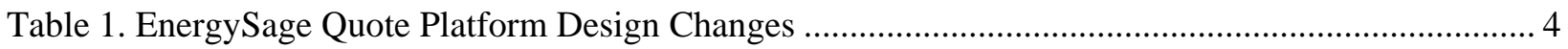

Table 2. Design Change Objectives and Evidence to Test Effects ........................................................ 9

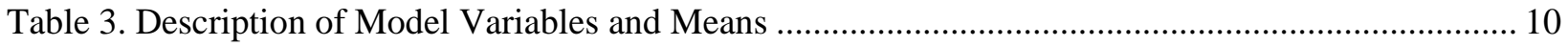

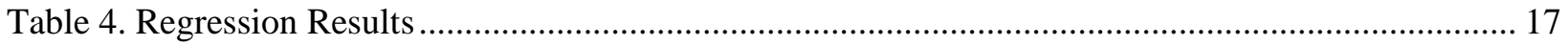

Table 5. Design Change Effect Robustness Checks .............................................................................. 19

Table 6. Summary of Platform Design Changes and Their Effects ........................................................ 21 


\section{Introduction}

The vast majority of residential solar photovoltaic (PV) customers in the United States procure PV by obtaining price quotes directly from PV installation companies (Mond 2017). More recently, customers increasingly have used online marketplaces, where they can compare quotes from multiple installers (Mond 2017). Online marketplaces and other market innovations could fundamentally change customer experiences during PV adoption, such as the quality and frequency of customer-installer interactions, the number of quotes received, and offer prices.

Quote platforms allow customers to obtain quotes from multiple installers relatively easily (Figure 1). Customers create an account with the online marketplace and provide basic information (e.g., address, electricity demand, preferences about equipment attributes) that allows installers to develop site-specific quotes. The marketplace administrator, also known as the quote aggregator, conveys this customer information to a network of PV installers. Aggregators may develop specific requirements for installer participation, such as minimum years of experience or certification level. Interested installers then develop quotes -including a price, system size, and other system specifications - and submit the quotes to the online platform. The customer can then compare all submitted quotes.

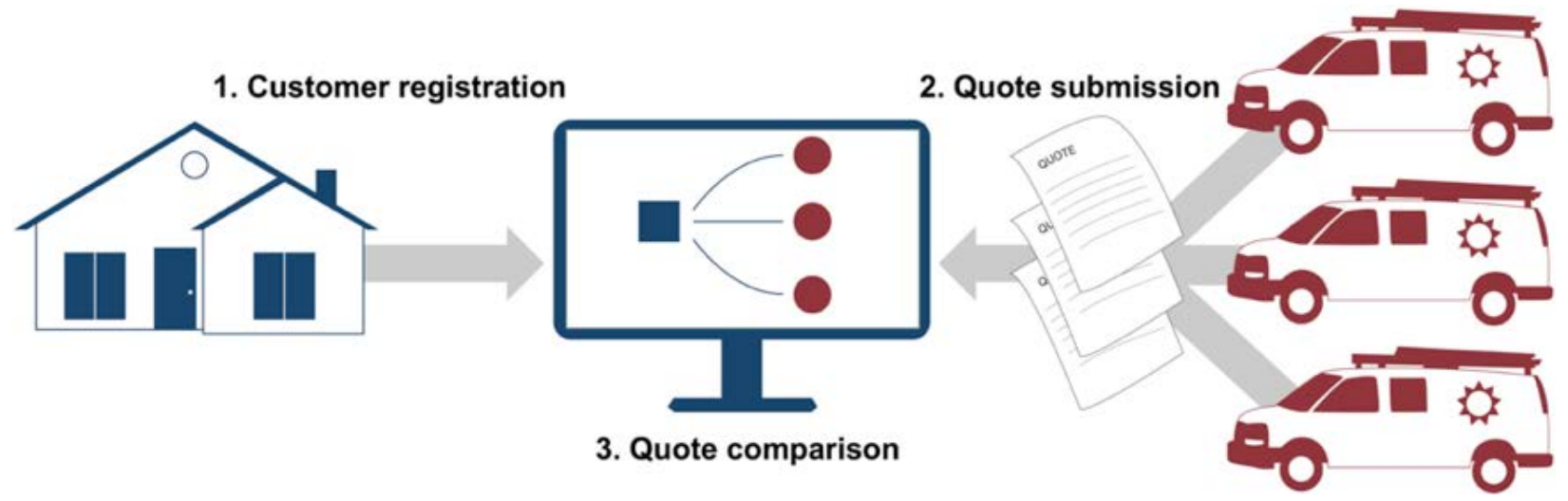

Figure 1. Schematic of online PV quote platforms

Quote platforms can be interpreted as a type of multi-dimensional auction, where customers compare products from multiple bidders (installers) along dimensions of price and product attributes (e.g., system size, PV panel brand) and select the product that provides the greatest net value, or choose not to make a purchase. The robust literature of auction theory shows auction design plays a critical role in auction outcomes (Myerson 1981, McAfee and McMillan 1987, Che 1993, Klemperer 2002).

This study analyzes the degree to which quote platform design affects customer experiences in online marketplaces in terms of quantifiable factors such as prices, wait times, and equipment quality. Using quote data provided by the U.S. quote aggregator EnergySage, we study how four platform design changes affected various aspects of the customer experience. Section 2 summarizes quote platform design and the four design changes in our study. Section 3 describes our data and methods. Section 4 provides results, and Section 5 concludes the report. 


\section{Quote Platform Design}

This section discusses quote platform design. In Section 2.1, we address design in general. In Section 2.2, we discuss the EnergySage platform in particular, providing the basis for our empirical work in the remainder of the report.

Quote platforms may vary along a number of dimensions (Figure 2). For simplicity, we divide quote platform design into three information flows:

- The installer information flow refers to the information that the aggregator requires from customers and provides to installers. This information flow may include other relevant market information provided by the aggregator like the number of other installers active in the customer's market or average prices in the area.

- The customer information flow refers to the information that the aggregator requires from installers and provides to customers. This flow includes all information that installers must provide to be able to post quotes to the platform. This flow may include other relevant market information provided by the aggregator such as average prices in the customer's area.

- The open communication channel refers to any open communication between the customer and the installer, which may or may not be mediated by the aggregator.

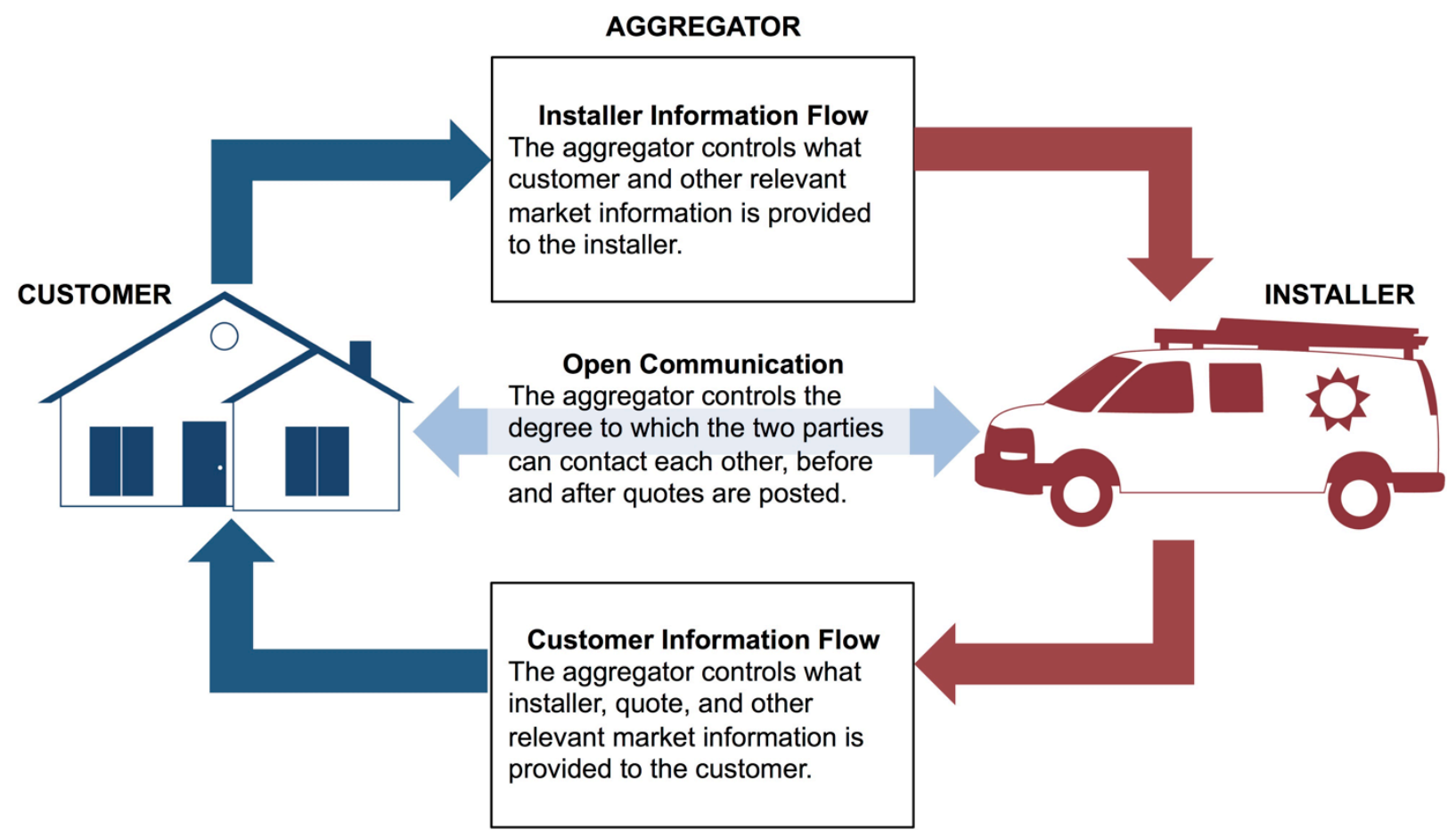

Figure 2. Quote platform design elements 


\subsection{Platform Design and PV Customer Outcomes}

In general, platform designs that optimize customer information flows should improve customer outcomes. Optimization in this context does not imply maximization. One of the benefits of quote platforms is their ability to restrict the flow of superfluous information. When providing quotes directly to customers, individual installers may provide different levels of detail and use different quote formats. They may also employ various sales tactics to promote their brand or reputation that do not necessarily convey meaningful information about the quoted system. On quote platforms, customers can compare multiple quotes conveying the same level of detail in a common format. An optimized design provides the minimum amount of information necessary for customers to make an informed decision and restricts superfluous information that may confuse customers. An optimal customer information flow may include system information (e.g., size, panel brand), installer information (e.g., years of experience, certifications), and market information (e.g., average prices in the customer's market).

Similarly, designs that optimize installer information flows should improve customer outcomes. At a minimum, installers need enough customer site-specific information to develop an accurate cost estimate. Excessive restrictions on installer information flows could result in inaccurate quotes that may need to be adjusted in subsequent stages of the adoption process. At the same time, quote platforms can restrict installer information flows for superfluous information that may reveal the customer's valuation of PV. For instance, installers may be able to use information about customer electricity use to mark up or discount prices based on the potential benefits customers would accrue from PV adoption - a practice known as value-based pricing (Barbose et al. 2015, Gillingham et al. 2016). Certain restrictions on installer information flows may improve customer outcomes by limiting the ability of installers to set value-based prices.

The effects of open communication are more nuanced. Open communication may help customers communicate idiosyncratic demands to installers, and it may help installers differentiate their services. Further, open communication allows both parties to obtain additional information that is either excluded from or overly vague on the quote platform. At the same time, open communication may increase customer vulnerability to conventional sales tactics and valuebased pricing, especially if it is allowed before quotes are posted to the platform. Aggregators can restrict open communication by masking customer and installer identities to varying degrees. For instance, the aggregator may withhold all contact information about both parties but allow each party to communicate via messaging on the quote platform.

\subsection{Design Changes on the EnergySage Quote Platform}

Because of concerns about disclosing proprietary information, we do not provide an in-depth description of the design of EnergySage's quote platform. ${ }^{1}$ However, for the purposes of this study, EnergySage described four design changes it has implemented since 2016 (Table 1).

\footnotetext{
${ }^{1}$ Different quote platforms have different designs, so the results of this study are not necessarily externally valid under other platform designs. However, EnergySage is currently the largest quote platform in the United States in terms of number of quotes processed. Thus the platform design studied in this report is generally representative of a typical customer experience in the United States.
} 
Table 1. EnergySage Quote Platform Design Changes

\begin{tabular}{|c|c|c|c|}
\hline Design change & Date & Type & Description \\
\hline Customer map & May 2016 & $\begin{array}{l}\text { Customer } \\
\text { information flow }\end{array}$ & $\begin{array}{l}\text { At the beginning of registration, potential new } \\
\text { customers can view a map showing the locations } \\
\text { of other customers in the area that have obtained } \\
\text { quotes on the platform. }\end{array}$ \\
\hline Quote cap & July 2016 & $\begin{array}{l}\text { Customer } \\
\text { information flow }\end{array}$ & $\begin{array}{l}\text { The maximum number of quotes received by } \\
\text { each customer is capped at seven. }\end{array}$ \\
\hline Price guidance & $\begin{array}{l}\text { March } \\
2017\end{array}$ & $\begin{array}{l}\text { Installer } \\
\text { information flow }\end{array}$ & $\begin{array}{l}\text { Installers are provided information about } \\
\text { competitive prices in the customer's market } \\
\text { before submitting a quote. }\end{array}$ \\
\hline $\begin{array}{l}\text { No pre-quote } \\
\text { messaging }\end{array}$ & June 2017 & $\begin{array}{l}\text { Open } \\
\text { communication }\end{array}$ & $\begin{array}{l}\text { Installers are prohibited from sending messages } \\
\text { to customers before posting a quote to the } \\
\text { platform. }\end{array}$ \\
\hline
\end{tabular}

Based on discussions with EnergySage and findings from the literature, we form hypotheses about how these four design changes may affect customer experiences.

\subsubsection{Customer Map}

Since May 2016, potential new EnergySage customers can view a map of other customers in the area that have obtained quotes on the platform (Figure 3). EnergySage implemented this change to provide more customer information during the initial stages of registration and convert more site visitors into registrants.

The customer map change could generate virtual peer effects: prospective customers may become more interested in PV adoption if they know peers are also interested in adoption. Peer effects play a key role in the diffusion of new technologies, including PV (Rogers 1983, Bollinger and Gillingham 2012, Noll et al. 2014, Rai et al. 2016). For instance, several studies show that drivers with peers who own hybrid or electric vehicles are more likely to buy hybrid or electric vehicles themselves (McCoy and Lyons 2014, McShane et al. 2012, Ozaki and Sevastyanova 2011). Bollinger and Gillingham (2012) find evidence of peer effects in PV adoption, showing that prospective PV customers are more likely to adopt when they have neighbors who have adopted.

The online customer map may enable virtual peer effects by conveying information about the popularity of PV in the customer's area. This new feature does not provide customers with additional information about price expectations, but it may empower customers to seek additional quotes and push for lower prices. 


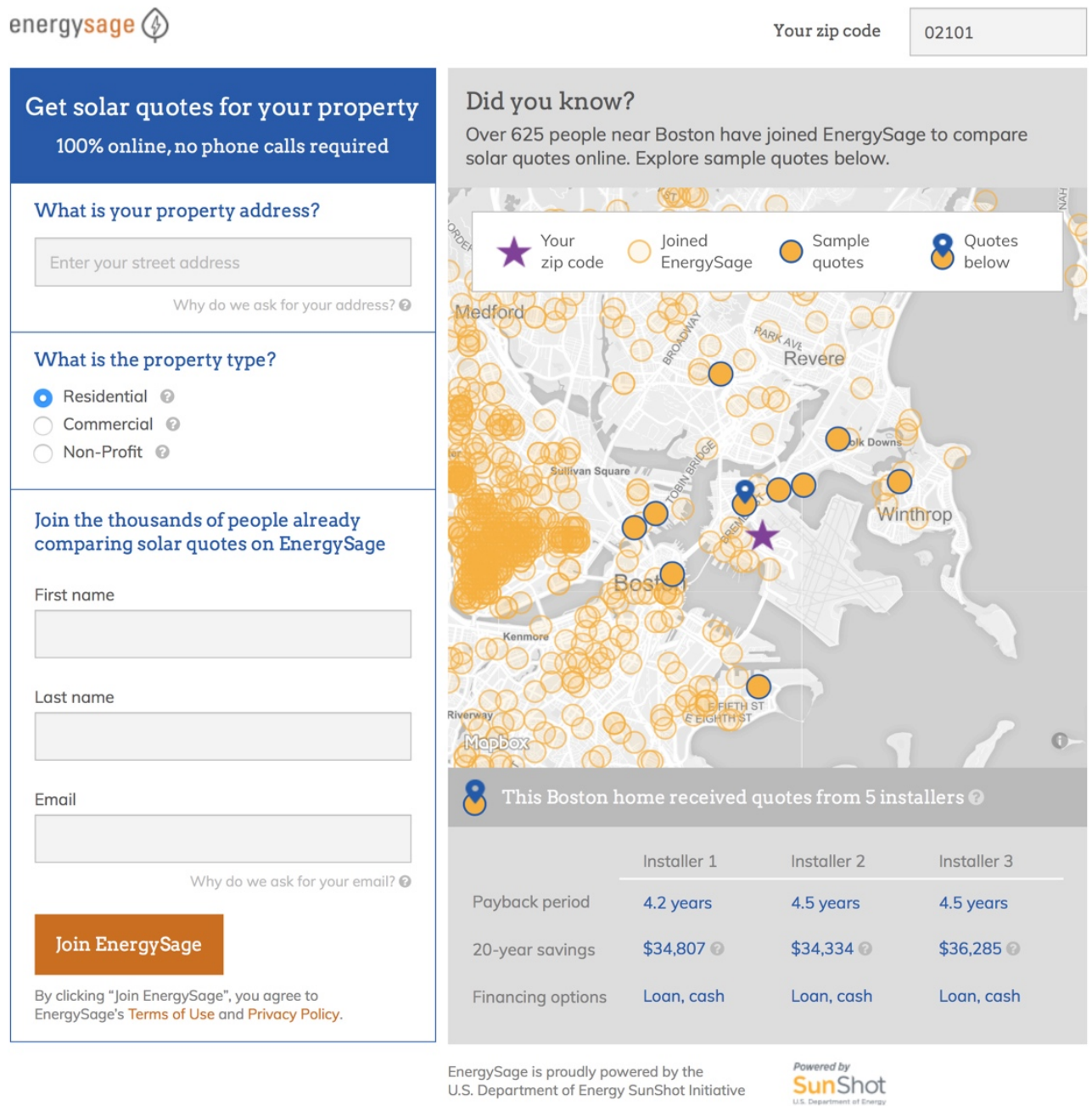

Figure 3. Screenshot of an EnergySage customer map

\subsubsection{Quote Cap}

In July 2016, EnergySage capped the maximum number of quotes provided to a given customer at seven. To secure an opportunity to submit a quote, an installer must express intent to bid to a customer on the platform. The first seven installers expressing intent are allowed to submit quotes. EnergySage implemented this change with three objectives: 1) to improve quote quality (e.g., higher-quality equipment, lower quote prices), 2) to shorten waiting times for customers to receive quotes, and 3) to reduce the frequency of installers expressing interest in bidding on a customer but not following through with a quote.

The potential effects of the quote cap on prices are somewhat ambiguous. EnergySage implemented the cap in response to customer and installer feedback describing information overload on the platform when many installers submitted quotes to the same customer. Capping the number of quotes could inflate prices, because quote prices generally decline as the number of quotes increases (O’Shaughnessy and Margolis 2017). However, the price benefits of receiving more quotes are diminishing, such that a high enough quote cap may not affect prices. 
Further, several studies suggest that capping the number of quotes could reduce prices under certain conditions (Satterthwaite 1979, Stiglitz 1979, Janssen and Moraga-Gonzalez 2004). The intuition behind these models is that firms have a very low probability of winning bids in markets where customers obtain many quotes. As a result, firms have an incentive to bid higher prices, effectively gambling on the possibility of the occasional high profit won from a customer who happens to receive few quotes. To the extent that installers exhibit this behavior, restricting the number of quotes might induce more competitive pricing.

\subsubsection{Price Guidance}

Since March 2017, installers in the EnergySage online marketplace are provided information about competitive prices in the customer's area before submitting a quote. The guidance is based on price data from EnergySage quotes made in the customer's area during the previous six months. EnergySage implemented the price guidance change with two goals in mind: 1) to tighten the distribution of quote prices offered by installers to a given customer, and 2) to help installers bid more intelligently and win more business as a result. The first objective was a reaction to feedback from customer surveys indicating wide quote price dispersion can cause some EnergySage customers to lose confidence in the platform.

The price guidance feature may have different impacts on the quote prices of different installers. The price guidance could act as an anchor (Tversky and Kahneman 1974), inducing installers to offer quotes close to the price guidance point. Galinsky and Mussweiler (2001) study anchoring in negotiations between buyer and seller, finding that first offer prices (the anchor) are strong predictors of final settlement prices. In this case, the price guidance point provided to installers may serve as the first offer, anchoring installers to a particular price point that will predict price offers. The price guidance could therefore induce high-price installers to offer lower prices, but could also induce low-price installers to offer higher prices.

\subsubsection{No Pre-quote Messaging}

Beginning in June 2017, installers can no longer message customers in the EnergySage online marketplace before submitting a quote. ${ }^{2}$ EnergySage implemented this change to prevent installers from using the quote platform solely as a lead-generation tool, i.e., using the platform to establish contact with customers but pursuing sales off the platform.

The no pre-quote messaging change could result in lower prices, because it reduces the possibility of price markups from high-pressure sales tactics or value-based pricing. ${ }^{3}$ At the same time, removing the opportunity for pre-quote messaging could negatively affect customers who are more interested in premium products, because it may be more difficult to signal a willingness to pay for premium equipment without pre-quote messaging. Likewise, the change may negatively affect installers that offer premium products by removing the opportunity to explain why these products justify higher prices.

\footnotetext{
${ }^{2}$ EnergySage provides information about its installer network to customers, so that customers could still theoretically contact EnergySage installers outside the platform.

${ }^{3}$ Some value-based pricing is still possible on the platform, given that installers have information about customer electricity use before offering a quote.
} 
The remainder of this report empirically explores the effects of the four quote platform design changes on various aspects of the customer experience, including quote prices received and prices actually paid to purchase PV. 


\section{Data and Methods}

In this section, we describe the data made available by EnergySage and the statistical methods applied to the data set. In Section 3.1, we summarize the data set, with details on number of quotes and system characteristics contained in the data. In Section 3.2, we outline descriptive approaches to evaluating the effects of the design changes on the specific customer experience elements they were intended to address. In Section 3.3, we develop a regression model to test the effects of the design changes on quote prices and purchase prices. In Section 3.4, we discuss our study's limitations.

\subsection{Data Set}

EnergySage provided data on 136,555 residential PV quotes made to 42,341 customers in 36 states and Washington, D.C., between 2013 and 2017. The data include a rich set of system characteristics such as quote price $(\$ / W)$, system size $(\mathrm{kW})$, and equipment used (panel and inverters types) as well as temporal variables such as quote date. The regression model developed in Section 3.3 is based on a subset of 126,594 quotes made to 41,333 customers from the complete data set. We dropped observations without an upfront system purchase price, with prices greater than $\$ 100 / \mathrm{W}$ (probable data-entry errors), or with systems larger than $1 \mathrm{MW}$ (probable data-entry errors). We also excluded quotes made by installers with less than 10 total quotes in the data set - to specify a model with installer fixed effects — and excluded quotes with missing values for variables included in our regression model. ${ }^{4}$

\subsection{Descriptive Tests}

Each platform design change was implemented with specific objectives to improve different aspects of the customer experience. We descriptively test the effects of each change by comparing the values of different customer experience variables before and after each change. We develop a separate test for each design change based on EnergySage's stated objectives for the change (Table 2). Objectives related directly to quote prices are assessed separately using the regression model outlined in the following subsection.

\footnotetext{
${ }^{4}$ More than 400 installers submitted at least one quote in the data set. Including installers with few quotes (less than 10) in regression models with installer fixed effects results in high multi-collinearity that can bias model results.
} 
Table 2. Design Change Objectives and Evidence to Test Effects

\begin{tabular}{|c|c|c|}
\hline Design Change & Objective & Test(s) \\
\hline Customer map & $\begin{array}{l}\text { Increase customer } \\
\text { information during initial } \\
\text { registration steps }\end{array}$ & $\begin{array}{l}\text { Customer site registration levels before } \\
\text { and after the change }\end{array}$ \\
\hline \multirow{3}{*}{ Quote cap } & Improve quote quality & $\begin{array}{l}\text { Percentage of quotes offering premium } \\
\text { panels before and after the change }\end{array}$ \\
\hline & Reduce customer wait time & $\begin{array}{l}\text { Number of days between customer } \\
\text { application and quote date before and } \\
\text { after the change }\end{array}$ \\
\hline & $\begin{array}{l}\text { Reduce instances of installers } \\
\text { expressing interest but not } \\
\text { submitting quotes }\end{array}$ & $\begin{array}{l}\text { Percentage of interested installers } \\
\text { submitting quotes before and after the } \\
\text { change }\end{array}$ \\
\hline Price guidance & Reduce quote price variability & $\begin{array}{l}\text { Coefficient of variation (standard } \\
\text { deviation divided by mean) }\end{array}$ \\
\hline No pre-quote messaging & Reduce offline sales tactics & $\begin{array}{l}\text { Number of quotes received per customer } \\
\text { before and after the change }\end{array}$ \\
\hline
\end{tabular}

a Absolute quote price variability has declined over time as PV prices have fallen. Through normalizing by the mean, the coefficient of variation reduces the influence of this temporal trend on measurements of price variability. The coefficient of variation is the most common metric to measure price variability (Nemet et al. 2017).

\subsection{Regression Model}

Quote prices play a key role in the online platform customer experience. Furthermore, prices are easily quantifiable and comparable across quotes and customers, especially when controlling for other system characteristics that determine prices. We develop a regression model to investigate the impact of key quote-price drivers on the EnergySage platform.

We model quote price as a function of system characteristics (e.g., system size, type of inverter, panel quality), competition, quote date, and customer characteristics. During EnergySage's bidding process, installers are unaware of which rivals submit quotes and of the prices of those quotes. However, installers can see the number of interested installers when submitting their bids. The number of expressions of intent is highly correlated with the number of quotes that customers ultimately receive, and thus may help installers estimate the number of rivals bidding on any given customer (O’Shaughnessy and Margolis 2017). We refer to this number of expressions of intent as the expected competition. Auction theory and findings from O’Shaughnessy and Margolis (2017) suggest that the degree of expected competition has a direct impact on quote prices. In general, this literature suggests that quote prices decline exponentially with the number of quotes received by customers (Carr 1983, McAfee and McMillan 1987, Rothkopf and Harstad 1994, Lorentziadis 2016). We take a log transformation of expected competition to account for this exponential relationship. Our basic model is:

$$
p=\operatorname{comp} \lambda+\boldsymbol{X} \beta+C T Y+I N S T+\varepsilon
$$


Here, $p$ is the quote price (\$/W), comp is the natural log of expected competition, and $\boldsymbol{X}$ is a matrix of control variables for system size, the customer's annual electricity use, and system hardware. $C T Y$ is a county fixed effect, INST is an installer fixed effect, and $\varepsilon$ is the error term. The coefficients $\lambda$ and $\beta$ represent the degrees to which the explanatory variables affect quote prices. Table 3 describes all variables as well as their mean values.

Table 3. Description of Model Variables and Means

\begin{tabular}{|c|c|c|c|c|}
\hline Variable & Units & Description & $\begin{array}{l}\text { Mean } \\
\text { (st. dev) }\end{array}$ & Min/Max \\
\hline$p$ : quote price & $\$ / W$ & Quote price & $\begin{array}{c}3.39 \\
(0.54)\end{array}$ & $0.16 / 28$ \\
\hline $\begin{array}{l}\text { comp: expected } \\
\text { competition }\end{array}$ & $\begin{array}{l}\text { total intents } \\
\text { (logged) }\end{array}$ & $\begin{array}{l}\text { Natural log of total number of } \\
\text { interested installers }\end{array}$ & $\begin{array}{c}1.60 \\
(0.51)\end{array}$ & $0 / 2.89$ \\
\hline quarter & 3 months (linear) & $\begin{array}{l}\text { Controls for temporal decline } \\
\text { in prices }\end{array}$ & - & - \\
\hline CTY: county & - & $\begin{array}{l}\text { Fixed effect to control for } \\
\text { geographical differences in } \\
\text { prices }\end{array}$ & - & - \\
\hline INST: installer & - & $\begin{array}{l}\text { Fixed effect to control for } \\
\text { installer price differences }\end{array}$ & - & - \\
\hline system size & $\mathrm{kW}$ & $\begin{array}{l}\text { Control for economies of } \\
\text { scale in system size }\end{array}$ & $\begin{array}{c}8.2 \\
(4.68)\end{array}$ & $0.27 / 216$ \\
\hline $\begin{array}{l}\text { system size } \\
\text { squared }\end{array}$ & $\mathrm{kW}^{2}$ & $\begin{array}{l}\text { Control for diminishing } \\
\text { returns to scale }\end{array}$ & $\begin{array}{c}89.6 \\
(271.9)\end{array}$ & $0.07 / 46,656$ \\
\hline $\begin{array}{l}\text { customer's } \\
\text { annual } \\
\text { electricity use }\end{array}$ & kWh/year & $\begin{array}{l}\text { Customer-entered estimate of } \\
\text { electricity use, control for } \\
\text { value-based pricing }\end{array}$ & $\begin{array}{c}13,500 \\
(10,159)\end{array}$ & $12 / 1,072,164$ \\
\hline panel rating & $\begin{array}{l}\text { factor: economy, }{ }^{*} \\
\text { standard, premium }\end{array}$ & $\begin{array}{l}\text { Control for price differences } \\
\text { based on panel cost. } \\
\text { Premium } \geq 20 \% \text { efficiency, at } \\
\text { least } 20 \text {-year warranty; } \\
\text { Standard } \geq 16.5 \% \text { efficiency, } \\
\text { at least } 15 \text {-year warranty }\end{array}$ & - & - \\
\hline inverter type & $\begin{array}{l}\text { factor: micro, }{ }^{\star} \text { DC } \\
\text { optimizer, string }\end{array}$ & $\begin{array}{l}\text { Control for price differences } \\
\text { based on inverter cost }\end{array}$ & - & - \\
\hline
\end{tabular}

* One factor variable must be taken as the reference in linear regression; economy and micro are taken as references in this case. 
To estimate the effects of the platform design changes discussed in Section 2 on quote prices, we incorporate regression discontinuities into the model described in Equation (1). Regression discontinuity analyzes mean values before and after a point in time (the discontinuity) while controlling for all other variables in the regression model. The modified regression model is:

$$
p=\operatorname{comp} \lambda+\boldsymbol{X} \beta+C M \beta_{C M}+Q C \beta_{Q C}+P G \beta_{P G}+N M \beta_{N M}+C T Y+I N S T+\varepsilon
$$

In this specification, $C M, Q C, P G$, and $N M$ are dummy variables that take on a value of zero if the quote was made before and a value of one if it was made after each of the design changes: customer map $(C M)$, quote cap $(Q C)$, price guidance $(P G)$, and no pre-quote messaging $(N M)$. The coefficients $\beta_{C M}, \beta_{Q C}, \beta_{P G}$, and $\beta_{N M}$ measure the changes in price attributable to each of the respective platform design changes.

Models (1) and (2) are run on both the full data set and a subset of the data restricted to only the accepted quotes (purchase prices). Regressions using the accepted quote data set are included to understand how customers actually value system characteristics, with specific focus on panel quality. Some PV installers have expressed concern that online PV marketplaces may increase customer focus on price relative to other system characteristics like panel warranties, although O’Shaughnessy and Margolis (2017) find no evidence of price-centrism on the EnergySage platform. We further test the degree to which online shoppers value premium panels by repeating the same regression on both the full data set and the subset of accepted quotes. Any change in the coefficients for the price effects of panel quality between the full data set and the accepted quote data set could suggest customers are willing to pay more or less for premium panels than installers account for in their quote prices.

\subsection{Limitations}

The primary limitation of our study is that we rely on observed differences before and after design changes rather than a random-controlled experimental design. Observed differences before and after design changes may be biased by broader platform and market trends. For instance, price differences before and after platform changes may be biased by falling prices overall. Our regression discontinuity design attempts to control for these temporal biases. We provide additional robustness checks for our results in Section 4.6. 


\section{Results}

In this section, we show the effects of platform design changes on the EnergySage customer experience. In Sections 4.1-4.4, we examine how effectively each platform design change accomplished its specific objectives. Section 4.5 provides the results of the price regression models described in Section 3.3. Section 4.6 includes robustness checks, and Section 4.7 contains additional analyses on customer valuation of panel quality.

The descriptive analyses in Sections 4.1-4.4 are provided to describe general trends observed in the data. We do not attempt to test the statistical significance of differences in specific variables before and after the platform design changes in the descriptive analyses, because the observed outcomes may be confounded by broader temporal trends. EnergySage reports that each of the design changes was implemented in isolation without other significant changes such as marketing campaigns.

\subsection{Customer Map}

The customer map change increased the knowledge of customers about PV interest in their area. Virtual peer effects from the customer map change may make interested customers more likely to register on the EnergySage site. To test this hypothesis, Figure 4 displays the number of customer registrations per month as a ratio to the number of customer registrations in May $2016,{ }^{5}$ the month of the customer map change. Figure 4 shows customer registrations steadily increasing over time as the quote platform grew prior to the change, followed by a sharp increase in customer registrations after the customer map change-suggesting the customer map enhanced customer comfort with the platform and increased registrations. Monthly customer registrations increased by about $250 \%$ in the six months after the customer map change relative to the six months prior to the change. EnergySage reports that the customer map change was not accompanied by any specific change in the company’s advertising or marketing strategy.

\footnotetext{
${ }^{5}$ The ratio is used rather than the actual number of registrations owing to the proprietary status of the data. Registration data were provided by EnergySage.
} 


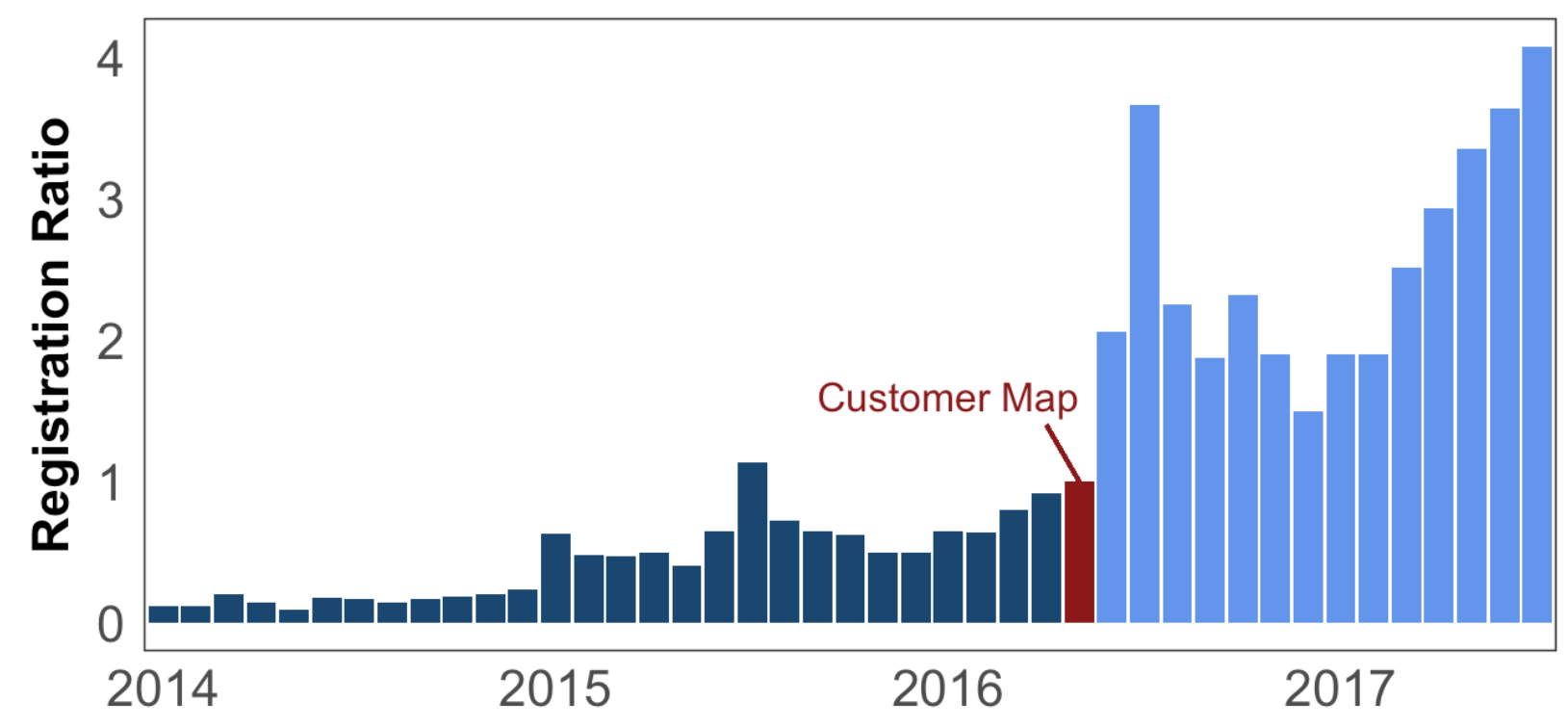

Figure 4. Registration ratio* before and after the customer map change

* Defined as the ratio of customer registrations in each month relative to the number of registrations in May 2016. The ratio is provided rather than the actual value owing to the proprietary status of the data.

The coefficient for the customer map change from the regression model (Section 4.5, Table 4) suggests that quote prices on the platform fell by about $\$ 0.04 / \mathrm{W}$ on average after the change, holding all other factors constant. On the one hand, this result is counterintuitive, especially if the customer map change increased demand on the platform as suggested by the results in Figure 4. On the other hand, the customer map may have caused some customers to take PV adoption more seriously owing to peer effects. If so, customers after the customer map change may have been more invested in PV adoption and thus pushed for lower prices, ${ }^{6}$ causing platform prices to fall overall. However, this result lost statistical significance in a subsequent robustness test (Section 4.6).

\subsection{Quote Cap}

EnergySage implemented the quote cap with three stated objectives: 1) to improve quote quality, 2) to shorten waiting times to receive quotes, and 3) to reduce the frequency of installers expressing interest in bidding on a customer but not following through with a quote. The quote cap is only relevant in states where customers tended to receive as many or more quotes than the cap prior to the change. We limit the analysis in this section to quotes in California, Massachusetts, New Jersey, and New York - markets where the cap was likely binding. Figure 5 depicts a trend consistent with the first objective to improve panel quality. The figure shows the percentage of quotes per month that offered a premium panel (at least $20 \%$ efficiency and at least a 20-year warranty). The share of quotes using premium panels appears to increase after the quote cap was implemented in July 2016 and remain relatively high. About $6.6 \%$ of quotes offered a premium panel in the six months after the change, compared with about $5.7 \%$ of quotes offered in the six months prior to the change.

\footnotetext{
${ }^{6}$ Quote prices in the data set represent the last offer price made by an installer to a customer. Quotes may be updated during the process, such that customers may return to installers to request lower prices when considering adoption.
} 


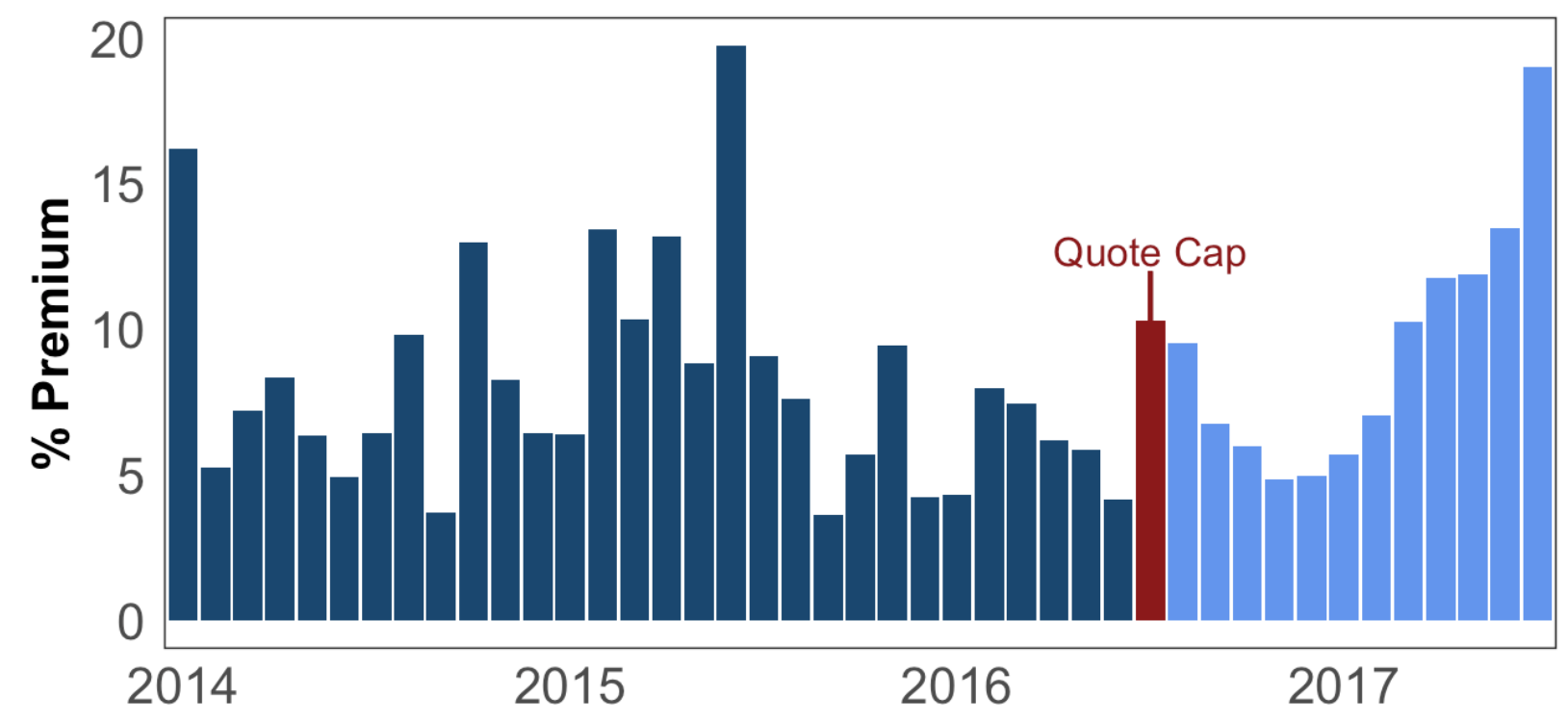

Figure 5. Percentage of quotes offering premium panels before and after the quote cap change

Figure 6 shows quote waiting times in terms of the number of days between the customer's application and the quote date. Wait times declined steadily over several years, possibly reflecting installers growing accustomed to the online platform. Customer wait times were about half a day shorter on average in the six months after the quote cap change than in the six months prior. However, Figure 6 suggests that at least some of this difference is part of the broader trend toward shorter wait times as installers became more efficient on the site.

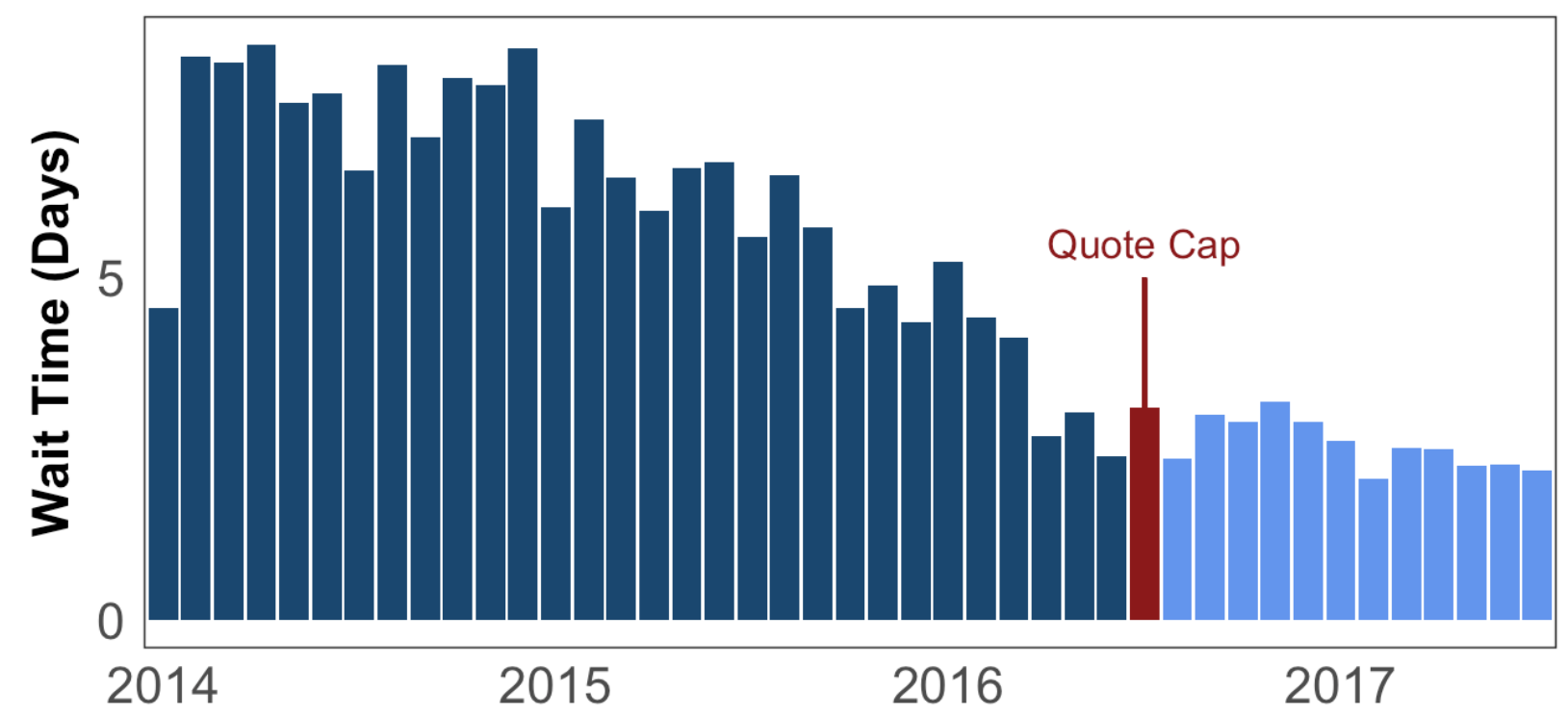

Figure 6. Customer wait time (days between application and quote delivery) before and after the quote cap change

Lastly, Figure 7 displays the percentage of installers expressing interest in a customer and ultimately submitting a quote, indicating that the quote cap increased the percentage. About 78\% of interested installers submitted quotes in the six months after the quote cap change, compared with about $70 \%$ of interested installers in the six months prior. 


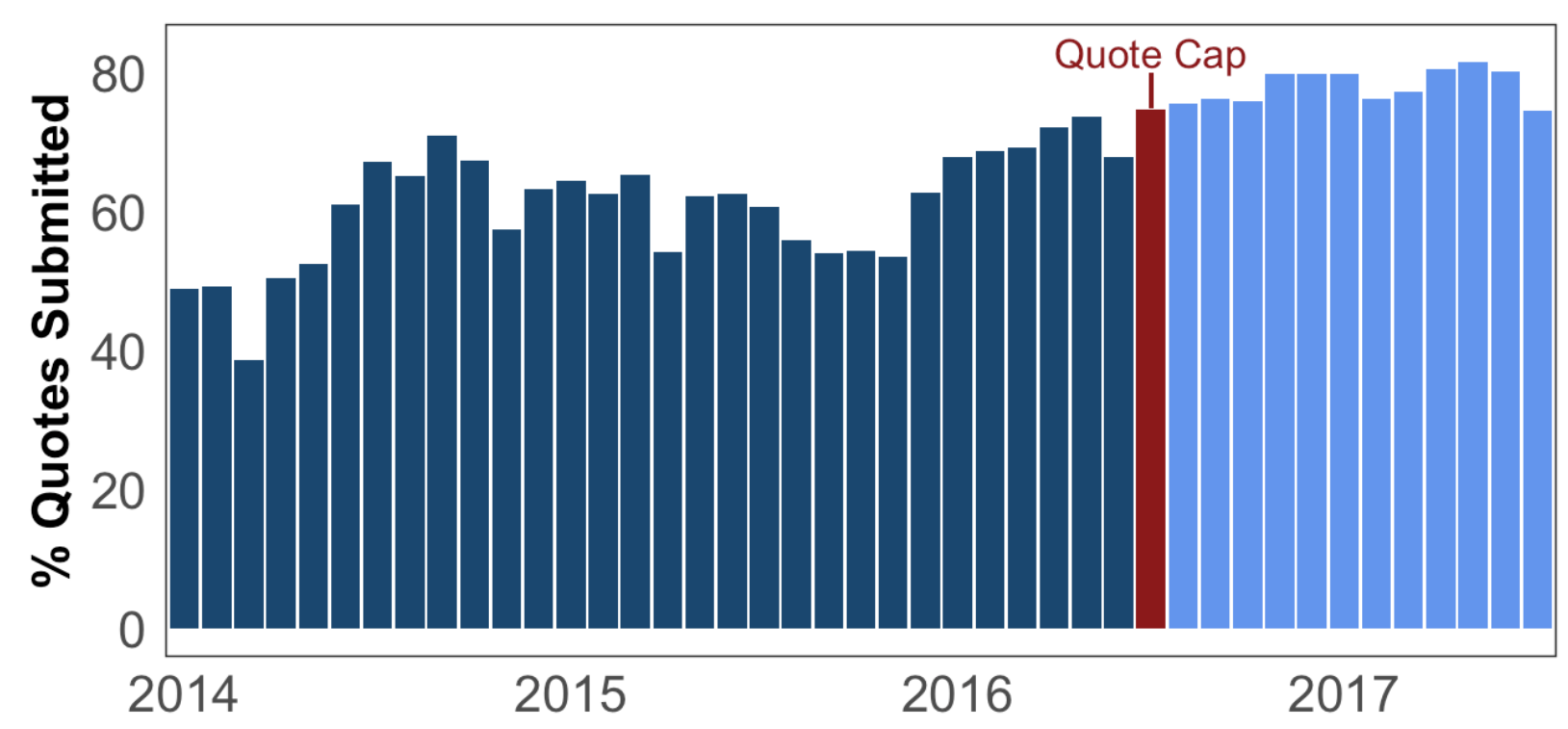

Figure 7. Percentage of installers expressing interest in a customer and ultimately submitting a quote, before and after the quote cap change

The regression results suggest that quote prices were about $\$ 0.05 / \mathrm{W}$ lower after the quote cap change, on average, holding all other factors constant (Section 4.5, Table 4). This result is particularly interesting, given that the negative coefficient appears to contradict auction theory and empirical findings. The result supports hypotheses from several models suggesting prices may increase as customers obtain more quotes in markets where customers receive many quotes (Satterthwaite 1979, Stiglitz 1979, Janssen and Moraga-Gonzalez 2004). In these markets, medium- and high-price installers face little incentive to offer lower prices, because these prices are very likely to be undercut by low-price installers. Instead, medium- and high-price installers may strategically bid higher prices in these markets to win a high profit margin occasionally on customers who happen to receive few quotes. Capping the number of quotes received may reduce the incentives for this type of opportunistic bidding behavior. This interpretation is supported by the results of Regression (4), which is limited to accepted quotes. The coefficient for quote cap is almost zero here and not statistically significant, suggesting the quote cap change had a significant impact on the prices of all quotes but little impact on the prices of accepted quotes. In other words, the change appears to have affected the prices of installers that were losing quotes more than the prices of installers that were winning quotes.

\subsection{Price Guidance}

EnergySage implemented the price guidance change to educate installers about locally competitive prices and reduce quote price dispersion. Figure 8 illustrates quote price variation over time in terms of the coefficient of variation (standard deviation divided by mean). Price variation appears to have fallen over time in general, even before the price guidance change. The coefficient of variation in the six months after the price guidance change was about 0.147 , compared with 0.149 in the six months prior. 


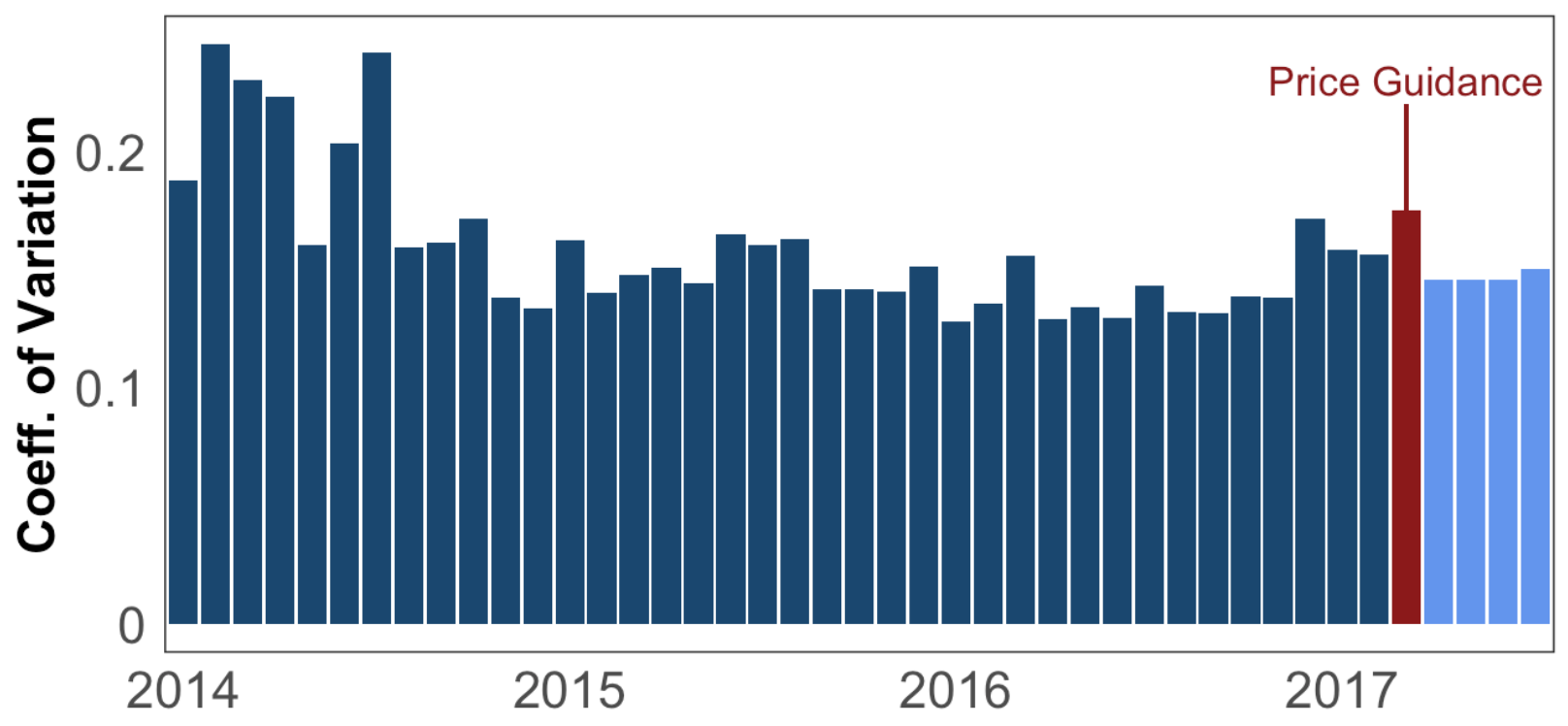

Figure 8. Price variability (coefficient of variation) before and after the price guidance change

The price guidance change had the most significant effect on quote prices: the results indicate that mean prices fell by about $\$ 0.11 / \mathrm{W}$ after the design change, holding all other factors constant (Section 4.5, Table 4). This result was expected, because this design change directly guides installer pricing strategy rather than indirectly affecting prices by guiding customers. The finding is consistent with the hypothesis that price guidance leads to anchoring, discussed in Section 2.2. Specifically, the results suggest that the price guidance serves as an anchor pulling prices generally downward toward the price guidance point. In other words, some high-price installers may have realized that customers were accepting lower-priced quotes and decided to reduce prices to become more competitive. The results suggest price guidance is the most impactful design change in terms of prices.

\subsection{No Pre-quote Messaging}

Descriptive results of the no pre-quote messaging change were inconclusive, because the change occurred in the last few months of the data set. However, statistically significant results were obtained in the regression (Section 4.5, Table 4). The results of Regression (2) suggest that mean quote prices fell by $\$ 0.05 / \mathrm{W}$ after pre-quote messaging was prohibited, holding all other factors constant. As discussed in Section 2.2.4, removing the option of pre-quote messaging may have reduced the installers' ability to gauge customer willingness to pay a higher or lower price, thus reducing the installers' ability to set value-based prices.

\subsection{Price Regression Results}

Table 4 shows the complete results of four regressions. Regressions (1) and (2) show the results of models (1) and (2) for the full data set, respectively, while Regressions (3) and (4) show the results of models (1) and (2) limited to accepted quotes, respectively. The signs on the coefficients of all the control variables (non-highlighted rows) are consistent across all four models, suggesting the models are generally robust to the inclusion of the design changes. 
Table 4. Regression Results

$\mathrm{Y}=$ quote price $(\$ / \mathrm{W})$, $\mathrm{t}$-statistics in parentheses

\begin{tabular}{|c|c|c|c|c|}
\hline & $\begin{array}{l}(1) \\
\text { All quotes, no } \\
\text { design } \\
\text { changes }\end{array}$ & $\begin{array}{c}(2) \\
\text { All quotes, all } \\
\text { design } \\
\text { changes }\end{array}$ & $\begin{array}{c}\text { (3) } \\
\text { Accepted } \\
\text { quotes, no } \\
\text { design changes }\end{array}$ & $\begin{array}{c}\text { (4) } \\
\text { Accepted } \\
\text { quotes, all } \\
\text { design changes }\end{array}$ \\
\hline customer map & - & $\begin{array}{l}-0.037 \\
(6.6)^{a}\end{array}$ & - & $\begin{array}{l}-0.084 \\
(2.0)^{b}\end{array}$ \\
\hline quote cap & - & $\begin{array}{l}-0.049 \\
(9.7)^{\mathrm{a}}\end{array}$ & - & $\begin{array}{l}0.006 \\
(0.15)\end{array}$ \\
\hline price guidance & - & $\begin{array}{l}-0.105 \\
(29.2)^{\mathrm{a}}\end{array}$ & - & $\begin{array}{l}-0.149 \\
(5.0)^{\mathrm{a}}\end{array}$ \\
\hline $\begin{array}{l}\text { no pre-quote } \\
\text { messaging }\end{array}$ & - & $\begin{array}{l}-0.050 \\
(12.9)^{\mathrm{a}}\end{array}$ & - & $\begin{array}{c}-0.050 \\
(1.3)\end{array}$ \\
\hline $\begin{array}{l}\text { expected } \\
\text { competition }\end{array}$ & $\begin{array}{l}-0.009 \\
(3.03)^{b}\end{array}$ & $\begin{array}{l}-0.026 \\
(8.2)^{b}\end{array}$ & $\begin{array}{l}-0.068 \\
(2.7)^{\mathrm{b}}\end{array}$ & $\begin{array}{l}-0.076 \\
(3.0)^{\mathrm{b}}\end{array}$ \\
\hline system size & $\begin{array}{l}-0.028 \\
(67.8)^{a}\end{array}$ & $\begin{array}{l}-0.028 \\
(68.0)^{a}\end{array}$ & $\begin{array}{l}-0.065 \\
(8.4)^{\mathrm{a}}\end{array}$ & $\begin{array}{l}-0.064 \\
(8.2)^{a}\end{array}$ \\
\hline system size ${ }^{2}$ & $\begin{array}{c}2.000 \mathrm{e}-04 \\
(36.5)^{\mathrm{a}}\end{array}$ & $\begin{array}{c}2.000 \mathrm{e}-04 \\
(36.4)^{\mathrm{a}}\end{array}$ & $\begin{array}{l}0.001 \\
(3.4)^{\mathrm{a}}\end{array}$ & $\begin{array}{c}0.001 \\
(3.23)^{\mathrm{a}}\end{array}$ \\
\hline annual elec. use & $\begin{array}{c}1.863 \mathrm{e}-06 \\
(12.4)^{\mathrm{a}}\end{array}$ & $\begin{array}{c}1.874 \mathrm{e}-06 \\
(12.5)^{\mathrm{a}}\end{array}$ & $\begin{array}{c}5.617 \mathrm{e}-06 \\
(3.0)^{\mathrm{a}}\end{array}$ & $\begin{array}{c}5.272 \mathrm{e}-06 \\
(2.8)^{\mathrm{a}}\end{array}$ \\
\hline standard panel & $\begin{array}{l}0.042 \\
(7.6)^{a}\end{array}$ & $\begin{array}{l}0.043 \\
(7.8)^{a}\end{array}$ & $\begin{array}{l}0.070 \\
(1.6)\end{array}$ & $\begin{array}{l}0.065 \\
(1.5)\end{array}$ \\
\hline premium panel & $\begin{array}{l}0.495 \\
(70.5)^{\mathrm{a}}\end{array}$ & $\begin{array}{l}0.510 \\
(72.9)^{\mathrm{a}}\end{array}$ & $\begin{array}{c}0.627 \\
(11.9)^{\mathrm{a}}\end{array}$ & $\begin{array}{c}0.643 \\
(12.2)^{\mathrm{a}}\end{array}$ \\
\hline $\begin{array}{l}\text { DC optimizer } \\
\text { inverter }\end{array}$ & $\begin{array}{l}-0.036 \\
(9.9)^{a}\end{array}$ & $\begin{array}{l}-0.036 \\
(9.9)^{a}\end{array}$ & $\begin{array}{c}-0.044 \\
(1.5)\end{array}$ & $\begin{array}{c}-0.047 \\
(1.6)\end{array}$ \\
\hline string inverter & $\begin{array}{l}-0.067 \\
(13.5)^{\mathrm{a}}\end{array}$ & $\begin{array}{l}-0.049 \\
(9.9)^{a}\end{array}$ & $\begin{array}{l}-0.110 \\
(3.1)^{\mathrm{a}}\end{array}$ & $\begin{array}{l}-0.084 \\
(2.4)^{b}\end{array}$ \\
\hline quarter & $\begin{array}{c}-0.068 \\
(126.1)^{\mathrm{a}}\end{array}$ & $\begin{array}{l}-0.041 \\
(41.0)^{a}\end{array}$ & $\begin{array}{l}-0.062 \\
(15.4)^{\mathrm{a}}\end{array}$ & $\begin{array}{l}-0.036 \\
(5.3)^{\mathrm{a}}\end{array}$ \\
\hline county & $x$ & $x$ & $x$ & $x$ \\
\hline installer & $x$ & $x$ & $x$ & $x$ \\
\hline intercept & $\begin{array}{c}5.39 \\
(14.6)^{\mathrm{a}}\end{array}$ & $\begin{array}{c}4.96 \\
(13.5)^{\mathrm{a}}\end{array}$ & $\begin{array}{c}4.95 \\
(17.7)^{\mathrm{a}}\end{array}$ & $\begin{array}{c}4.62 \\
(16.2)^{a}\end{array}$ \\
\hline $\mathrm{R}^{2}$ & 0.54 & 0.54 & 0.72 & 0.72 \\
\hline
\end{tabular}

a Statistically significant at $p<0.01$

b Statistically significant at $p<0.05$ 
We can analyze the effects of these variables on quote prices. Expected competition is the natural log of the total number of interested installers; we can interpret its coefficient as the effect of doubling the number of expected competitors on the quote price. The coefficient in Regression (2) means quote prices fall by $\$ 0.03 / \mathrm{W}$ on average for each doubling of the number of expected competitors. That is, installers offer lower prices when expecting more competition, consistent with intuitive expectations and previous results (O’Shaughnessy and Margolis 2017). Further, standard and premium panels, as expected, have positive effects on the quote prices. Standard panels tend to cost around $\$ 0.04 / \mathrm{W}$ more than economy panels, whereas premium panels tend to cost around \$0.51/W more than economy panels. Of the 126,594 quotes, 10,975 quotes are for premium panels, whereas more than 100,000 quotes are for standard panels. Thus premium panels, which necessitate a higher quote price, may represent a high-quality, high-price niche market.

Regressions (2) and (4) in Table 4 show the results for the regression discontinuity models with the four design changes included. The effects of these design changes are presented in the first four highlighted rows of Table 4. All of the coefficients are negative, except for the statistically insignificant positive effect of the quote cap in Regression (4). The negative coefficients suggest that the design changes were generally associated with price reductions.

\subsection{Robustness Checks}

The coefficient on the quarter variable in Regression (1) suggests that PV prices on the platform fell over time by about $\$ 0.07 / \mathrm{W} /$ quarter, on average. In general, this result implies that prices were higher before and lower after any given date within the timeframe of the data. This temporal trend could bias the coefficients on the platform design changes, because these changes effectively compare prices before and after the design change implementation date. The inclusion of the quarter variable in the regression models should control for this temporal bias to some extent. To further ensure our results are not spurious owing to temporal trends, we perform robustness checks restricting the data to two months before and two months after these design changes, i.e., around the points of discontinuity. These data restrictions around the points of discontinuity should reduce any residual temporal bias.

We ran four variations of Regression (2) around each discontinuity, each regression limited to a single indicator variable for a single platform design change in isolation. The results of the quote cap, price guidance, and no pre-quote messaging changes are robust in this analysis, while the effects of the customer map change lose statistical significance (Table 5). The robustness checks suggest the price effects of the customer map change are relatively weak compared with the effects of the other changes, consistent with the change's relatively small coefficient in Regression (2), and they may be partially spurious owing to temporal price trends. 
Table 5. Design Change Effect Robustness Checks*

\begin{tabular}{lcc}
\hline \multicolumn{1}{c}{ Design change } & $\begin{array}{c}\text { Coefficient of corresponding } \\
\text { indicator variable }\end{array}$ & t-statistic \\
\hline Customer map & 0.003 & 0.3 \\
Quote cap & -0.036 & $5.0^{\mathrm{a}}$ \\
Price guidance & -0.036 & $3.6^{\mathrm{a}}$ \\
No pre-quote messaging & -0.03 & $5.4^{\mathrm{a}}$
\end{tabular}

* Here, we restrict the data set to just four months around the point of discontinuity for each design change (two months before and after the design change) and run the same regression as specified by Equation (2).

a Statistically significant at $p<0.01$

${ }^{\mathrm{b}}$ Statistically significant at $\mathrm{p}<0.05$

In all cases, the coefficients in Table 5 are smaller than the same coefficients in Table 4 . The reduced effects may reflect the reduced timeframes in the robustness analysis: the price effects of the changes may take more than two months to materialize fully. Alternatively, the larger coefficients in Table 4 could reflect at least some larger temporal trends in prices.

Figure 9 summarizes the results of the regression models and robustness checks. Three of the four effects in the all quotes model are negative, statistically significant, and robust, suggesting that the changes generally reduced prices on the platform.

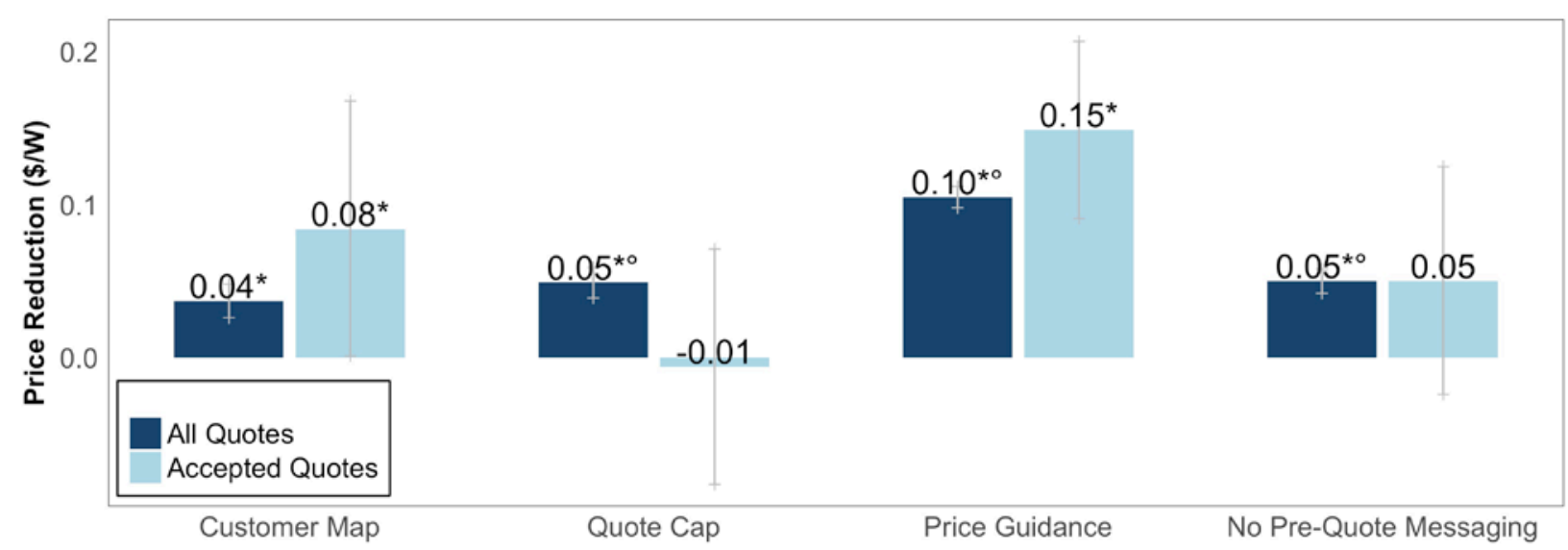

Figure 9. Effects of platform design changes on quote prices

Figure note: * Effect is statistically significant; ${ }^{\circ}$ Effect is robust (all quotes only), effects shown with $95 \%$ confidence intervals

\subsection{Valuation of Panel Quality}

Regressions (3) and (4) in Table 4 depict regression model results limited to accepted quotes. The coefficients for standard panel and premium panel are higher in the regressions limited to accepted quotes than in the regressions on the full data set. Comparing the coefficients on premium panels in Regressions (2) and (4) suggests average customer willingness to pay for 
premium panels is actually $\$ 0.13 / \mathrm{W}$ higher than the average markup for premium panels that installers incorporate into their quote prices (\$0.64/W compared with $\$ 0.51 / \mathrm{W}$ ). The apparent willingness of customers to pay for premium panels negates the hypothesis that customers are purely price-centric in online marketplaces. In fact, installers appear to be underestimating the additional price that customers are willing to pay for premium panel quality.

Another interesting observation is the change in the coefficients of expected competition in Regressions (3) and (4), compared with those in Regressions (1) and (2). The coefficient has the value $-\$ 0.076 / \mathrm{W}$ in Regression (4), which is restricted to only the accepted quotes. This is a much larger effect than the coefficient value $-\$ 0.026 / \mathrm{W}$ in Regression (2), for all quotes. In other words, it appears that competition has a stronger effect on purchase prices than it does on quote prices in general. Thus installers might underestimate the effect of competition on reducing the quote price required to win a customer as more competitors submit bids. 


\section{Discussion and Conclusion}

Online PV marketplaces can potentially enhance price transparency, generate lower prices, and improve customer outcomes. The design of these marketplaces can directly affect various aspects of the customer experience. We study the effects of four program design changes on the customer experience, including quote and purchase prices, within the EnergySage online marketplace. We find clear evidence of platform design affecting customer experiences. Three of the four design changes achieved at least some of EnergySage's objectives, and all four changes lowered quote prices on the platform, with three of the changes having particularly robust effects on prices (Table 6). Our results highlight the important role of platform design in online marketplaces.

Table 6. Summary of Platform Design Changes and Their Effects

\begin{tabular}{lll}
\hline \multicolumn{1}{c}{ Design Change } & Effect on Customer Experience & Effect on Prices \\
\hline $\begin{array}{l}\text { Customer map: Potential new } \\
\text { customers can view a map of all } \\
\text { online marketplace customers } \\
\text { in their area }\end{array}$ & $\begin{array}{l}\text { Virtual peer effects, increased site } \\
\text { registration }\end{array}$ & $-\$ 0.04 / \mathrm{W}^{\mathrm{a}}$ \\
$\begin{array}{l}\text { Quote cap: Customers can } \\
\text { receive no more than seven }\end{array}$ & $\begin{array}{l}\text { Supports shorter quote wait times, } \\
\text { may increase the percentage of } \\
\text { interested installers that ultimately } \\
\text { submit quotes }\end{array}$ & $-\$ 0.05 / \mathrm{W}^{\mathrm{b}}$ \\
$\begin{array}{l}\text { Price guidance: Installers can } \\
\text { view average prices in the } \\
\text { customer's area }\end{array}$ & $\begin{array}{l}\text { May reduce quote price variability } \\
\text { No pre-quote messaging: }\end{array}$ & $-\$ 0.10 / \mathrm{W}^{\mathrm{b}}$ \\
$\begin{array}{l}\text { Installers are prohibited from } \\
\text { messaging customers before } \\
\text { providing a quote }\end{array}$ & $\begin{array}{l}\text { Effects are unclear, objective is to } \\
\text { discourage off-platform bidding } \\
\text { and sales tactics }\end{array}$ & $-\$ 0.05 / \mathrm{W}^{\mathrm{b}}$ \\
$\begin{array}{l}\text { a Effect statistically significant at } \mathrm{p}<0.01 \\
\text { b Effect statistically significant at } \mathrm{p}<0.01 \text { and robust to subsequent checks }\end{array}$ & \\
\hline
\end{tabular}

As prospective residential PV customers increasingly turn to online quote aggregators to navigate the adoption process, the insights we have brought to light could help quote aggregators align platform design with installer, customer, and policy objectives. In particular, our findings on the effects of each platform design change have important policy implications for improving PV customer outcomes, lowering prices, and reducing price dispersion:

- The customer map result suggests virtual peer effects may motivate customers to pursue adoption and push for lower prices. Policymakers may leverage the concept of virtual peer effects and develop innovative methods and materials to spread awareness about current PV adoption rates through digital communications.

- The quote cap result suggests the benefits of more intense competition do not increase indefinitely as customers receive more quotes. Beyond some threshold number of quotes (the quote cap is equal to seven quotes), customers may be less able to compare different 
offers efficiently. Furthermore, markets where customers receive many quotes may induce installers to offer non-competitive prices. Policymakers may design programs that optimize — rather than maximize — competition by increasing customer access to competitive quotes while minimizing opportunistic bidding behavior.

- The effects of the price guidance change are consistent with an anchoring phenomenon in PV markets, where installers reduce prices down toward some anchor price. By increasing supply-side price transparency, policymakers may be able to encourage highprice installers to innovate and reduce costs down toward an anchor point, reducing market prices overall. The data suggest that the price guidance feature reduced price variability. This finding is particularly interesting, given the persistence of PV price dispersion and the possibility that this dispersion may erode customer confidence in adopting PV (Nemet et al. 2017). The findings suggest that price guidance policies—even outside the context of quote platforms - may be one approach to reducing PV price dispersion.

- The effects of the no pre-quote messaging change suggest some limitations on installercustomer interactions may yield better customer outcomes. Most customers are novices in the PV market, making them vulnerable to traditional sales tactics and value-based pricing. Policymakers could implement programs that provide customers with more price information before having to speak with an installer, such that customers are better equipped to enter into negotiations with installers. 


\section{References}

Barbose, G., N. Darghouth, S. Weaver, D. Feldman, R. Margolis, and R. Wiser. 2015. “Tracking U.S. photovoltaic system prices 1998-2012: a rapidly changing market.” Progress in Photovoltaics 23: 692-704.

Bollinger, B., and K. Gillingham. 2012. "Peer effects in the diffusion of solar photovoltaic panels.” Marketing Science 31(6): 900-912.

Carr, R.I. 1983. “Impact of number of bidders on competition.” Journal of Construction Engineering and Management 109(1): 61-73.

Che, Y.K. 1993. “Design competition through multidimensional auctions.” The RAND Journal of Economics: 668-680.

Galinsky, A.D., and T. Mussweiler. 2001. "First offers as anchors: the role of perspective-taking and negotiator focus.” Journal of Personality and Social Psychology 81(4): 657.

Gillingham, K., H. Deng, R. Wiser, N. Darghouth, G. Nemet, G. Barbose, V. Rai, and C.G. Dong. 2016. “Deconstructing solar photovoltaic pricing.” The Energy Journal 37(3): 231-250.

Klemperer, P. 2002. "What really matters in auction design.” The Journal of Economic Perspectives, 16(1): 169-189.

Janssen, M., and J.L. Moraga-Gonzalez. 2004. "Strategic pricing, consumer search and the number of firms.” Review of Economic Studies 71(4): 1089-1118.

Lorentziadis, P.L. 2016. "Optimal bidding in auctions from a game theory perspective.” European Journal of Operational Research 248(2): 347-371.

McAfee, R.P., and J. McMillan. 1987. “Auctions and bidding.” Journal of Economic Literature 25(2): 699-738.

McCoy, D., and S. Lyons. 2014. "Consumer preferences and the influence of networks in electric vehicle diffusion: An agent-based microsimulation in Ireland.” Energy Research \& Social Science 3: 89-101.

McShane, B.B., E.T. Bradlow, and J. Berger. 2012. "Visual influence and social groups.” Journal of Marketing Research 49(6): 854-871.

Mond, A. 2017. U.S. Residential Solar PV Customer Acquisition 2017. GTM Research.

Myerson, R.B. 1981. “Optimal auction design.” Mathematics of Operations Research 6(1): 5873.

Nemet, G., E. O’Shaughnessy, R. Wiser, N. Darghouth, G. Barbose, K. Gillingham, and V. Rai. 2017. Sources of Price Dispersion in U.S. Residential Solar Installations. LBNL-2001026.

Berkeley, CA: Lawrence Berkeley National Laboratory. 
Noll, D., C. Dawes, and V. Rai. 2014. "Solar community organizations and active peer effects in the adoption of residential PV.” Energy Policy 67: 330-343.

O’Shaughnessy, E., and R. Margolis. 2017. The Value of Transparency in Distributed Solar PV Markets. Golden, CO: National Renewable Energy Laboratory. NREL/TP-6A20-70095. https://www.nrel.gov/docs/fy18osti/70095.pdf.

Ozaki, R., and K. Sevastyanova. 2011. “Going hybrid: An analysis of consumer purchase motivations.” Energy Policy 39(5): 2217-2227.

Rai, V., D.C. Reeves, and R. Margolis. 2016. "Overcoming barriers and uncertainties in the adoption of residential solar PV.” Renewable Energy 89: 498-505.

Rogers, E. 1983. Diffusion of Innovations. New York, NY: The Free Press.

Rothkopf, M.H., and R.M. Harstad. 1994. “Modeling competitive bidding: A critical essay.” Management Science 40(3): 364-384.

Satterthwaite, M.A. 1979. "Consumer information, equilibrium industry price, and the number of sellers.” Bell Journal of Economics 10(2): 483-502.

Stiglitz, J.E. 1979. “Equilibrium in product markets with imperfect information.” American Economic Review 69(2): 339-345.

Tversky, A., and D. Kahneman. 1974. “Judgment under uncertainty: Heuristics and biases.” Science 185(4157): 1124-1131. 